\title{
Bridging the Gap between the PhD Thesis and the Publishable Research Article: A Corpus-Based Genre Analysis of Introductions in Applied Linguistics
}

Doktora Tezinden Yayınlanabilir Araştırma Makalesine Geçiş: Uygulamalı Dilbilim Alanında Yazılmış Giriș Bölümlerinin Derlem-Temelli Tür Analizi ${ }^{1}$

\author{
Elvan Eda Işık-Taş \\ Middle East Technical University, Turkey
}

\begin{abstract}
The aim of this multi-dimensional corpus-based study is to contrastively analyze the genre-specific features of introductions in a corpus of $\mathrm{PhD}$ theses in Applied Linguistics written at Turkish universities and the research articles published in reputable international academic journals in the same field. The move structure analysis conducted using the Create-a-Research-Space (CARS) Model (Swales 232) and the analysis of the lexico-grammatical features associated with the identified moves revealed extensive variations across the two sub-corpora. The hand-tagged move structure analysis was complemented with the electronic analysis of the data using a corpus software. One important finding was that the thesis authors tended to avoid Move 2, "establishing a niche" and inserted moves such as "stating assumptions" into their introductions, which were not aligned with the conventions of research articles. Research article authors, on the other hand, used Move 2 effectively through a wide range of linguistic strategies to highlight the significance of their study and to promote their work. Based on the findings, the paper offers awareness-raising strategies and pedagogical recommendations for novice writers who would like to recontextualize their theses as research articles and for graduate programs and thesis supervisors in assisting graduate students in this process.
\end{abstract}

Keywords: Research Article, PhD Thesis, Move Structure Analysis, Genre Analysis, Applied Linguistics

Öz

Bu derlem-temelli çalışmanın amacı Uygulamalı Dilbilim alanında Türkiye'de yazılmış doktora tezleri ve aynı alandaki uluslararası dergilerde yayınlanmış araştırma makalelerinin giriş bölümlerinin sözbilimsel ve dilbilgisel-sözcüksel özelliklerini karşıtsal olarak incelemektir. Swales'in CARS Model'i (231) kullanılarak yürütülen hareket/ adım yapısı analizi ve ortaya çıkan hareket ve adımlardaki dilbilgiselsözcüksel özelliklerin belirlenmesi iki alt derlem arasında önemli farklılıklar olduğunu göstermiştir. Elle işaretleme yöntemiyle yürütülen hareket/adım yapısı incelemesi, elektronik ortamda, derlem yazılımı kullanımıyla desteklenmiştir. Çalışmanın önemli bir bulgusu tez yazarlarının, araştırma makalelerinin zorunlu sözbilimsel özelliklerinden birisi olan "yer açma" (H2, İng., establishing a niche) gibi bazı hareketleri neredeyse hiç kullanmamalarına rağmen "varsayımları belirtme" (İng.

1 This paper, with updated corpus, is derived from my PhD Thesis: Işı Taş, Elvan Eda: $A$ Corpus-Based Analysis of Genre Specific Discourse of Research: The PhD Thesis and the Research Article in ELT. 2008. Middle East Technical University, PhD dissertation.

CUJHSS, December 2021; 15/2: 276-292.

(C) Çankaya University ISSN 1309-6761 Printed in Ankara

Submitted: May 29, 2021; Accepted: October 25, 2021

ORCID\#: 0000-0002-1856-1119; edaisik@metu.edu.tr 
stating assumptions) gibi makalelerde nadir görülen sözbilimsel hareketleri giriș bölümlerinde sıkça kullanmaları olmuştur. Makale yazarlarının ise H2'yi, zengin bir dilbilimsel çeşitlilikle kullandıkları ve çalışmalarının değerini bu strateji ile etkili bir biçimde vurguladıkları görülmüştür. Çalışma bulgularına dayanarak, bu makale, tezlerini araştırma makalesi olarak yeniden bağlamlandırmak isteyen deneyimsiz yazarlara ve bu süreçte onlara destek olan lisansüstü tez danışmanlarına farkındalık arttırıcı yöntemler ve pedagojik öneriler sunmaktadır.

Anahtar Kelimeler: Araştırma makalesi, doktora tezi, derlem analizi, hareket yapısı analizi, tür analizi, uygulamalı dilbilim

\section{Introduction}

Genres are not static or homogenous texts. They are dynamic entities and interact intertextually with other genres. According to Bakhtin (117), although texts might have ordered and unified forms (e.g., stories), they are also in a "dialogic" relationship with each other, that is, genres are ongoing processes of discourse production and they are always tied to other genres and cultures. With respect to academic genres, Swales' (21) "genre networks" and Bhatia's (181) "genre-mixing" concepts illustrate how genres in the research world intertextually interact with other genres. Presentations can be transformed into research articles (RAs), but just as likely, RAs can produce presentations. Similarly, RAs can precede or follow theses. This is in fact the process of "recontextualization," which is defined by Linell as follows:

Recontextualization involves the extrication of some part or aspect from a text or discourse, or from a genre of texts or discourses, and the fitting of this part or aspect into another context, i.e. another text or discourse (or discourse genre) and its use and environment. (154)

RAs and PhD theses (PhDTs) are in the same genre network and converting PhDTs into RAs is a very common practice in academia (22). Increasingly today, publishing a research article is seen as one of the obligatory stages of the thesis writing process. "PhDs by publication are also becoming far more common, with candidates being expected to publish three or more papers in peer reviewed journals in order to achieve the award" (Kamler and Thomson 138).

However, writing a research article is not an easy task for novice researchers, who begin their study as outsiders in the academic discourse community. This process is particularly difficult for English as a Lingua Franca (ELF) scholars, since they must deal with the challenge of both being novices in their field of study and the mastery of a new genre. Soler Monreal et al. (14), for instance, describe the rhetorical challenges that Spanish PhDT writers face in writing introductions. Novice ELF scholars, therefore, need to be supported in familiarizing themselves with the writing conventions as well as the research methods aligned with their disciplines (Samraj 15). However, the guidance provided in academic writing manuals rarely captures the inter-disciplinary (Hyland 28) and intra-disciplinary (Öztürk 35) variations in the rhetorical and 
lexico-grammatical features adopted in research writing. This study aims to address this gap by identifying the prevalent writing conventions in the field of Applied Linguistics and offering discipline specific suggestions for novice ELF scholars in recontextualizing their $\mathrm{PhD}$ theses as research articles.

The focus of this study is specifically the introduction sections of the PhDTs and the RAs because these texts are notoriously challenging for most academic writers. Swales comments:

The opening paragraphs somehow present the writer with a demoralizing number of options: decisions have to be made about the amount and type of background knowledge to be included; decisions have to be made about an authoritative versus a sincere stance; decisions have to be made about the winsomeness of the appeal to the readership; and decisions have to be made about the directness of the approach. (137)

As Harwood (1210) also discusses, capturing the readers' attention is more important than ever in today's academic world, in which countless studies are published daily. Therefore, the opening paragraphs of a RA is particularly significant in terms of promoting the research. This contrastive study aims to identify the rhetorical structure of introductions in RAs and PhDTs and to provide guidance for novice scholars in transforming their theses into RAs. To this end, the following research questions were formulated:

1. What is the move-step structure of RAs and PhD theses in Applied Linguistics?

2. What are the lexico-grammatical features within each move and step in RAs and $\mathrm{PhD}$ theses in Applied Linguistics?

3. How can Applied Linguistics PhDT introductions be recontextualized as RA introductions?

\section{Rhetorical Structure of RA and PhDT Introductions}

RA introductions are critical sites where authors perform promotional and persuasive discourse acts (Bruce 92; Afros and Schryer 62; Berkenkotter and Huckin 27; Bhatia 59; Swales 137). Extensive research in different disciplines has shown that expert authors use strategies to "promote" their studies (Bhatia 187; Harwood 1210), that is, they a create a niche for their research in the Introduction sections of their studies (e.g., Mogaddasi and Grave 80 in Mathematics; Öztürk 30, Wang and Jang 172, Hirano 245 in Applied Linguistics; Lu et al. 69, in Social Sciences; Afros and Schryer 65, in Humanities; Tessuto 20, in Law; Kanoksilapatham 75, in Engineering).

Swales' (232) Create-a-Research-Space (CARS) Model presents a useful framework to understand how writers create a promotional rhetorical structure in their texts. (fig. 1.). A move is "the defined and bounded communicative act that is designed to achieve one main communicative objective" (Swales and Feak 35). Swales' (232) CARS model presents three obligatory moves, which are 
further sub-divided into obligatory and optional steps, which are smaller units of discourse that build moves.

Fig. 1. The CARS Model (Swales 232)

Move 1 Establishing a territory (citations required)

Via

Topic generalizations of increasing specificity

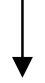

Move 2 Establishing a niche (citations possible)

Possible recycling of increasingly specific topics

Via

Step 1A Indicating a gap

or

Step 1B Adding to what is known

Step 2 (optional) Presenting positive justification

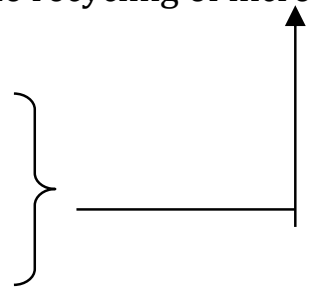

Move 3 Presenting the present work (citations possible)

Via

Step 1 (obligatory) Announcing present research descriptively and/or purposively

Step 2* (optional) Presenting RQs or hypotheses

Step 3 (optional) Definitional clarifications

Step 4 (optional) Summarizing methods

Step 5 (PISF**) Announcing principle outcomes

Step 6 (PISF) Stating the value of the present research

Step 7 (PISF) Outlining the structure of the paper

* Steps 2-4 are not only optional but less fixed in their order of occurrence than others.

** PISF: Probable in some fields, but unlikely in others

In the first move of the Model (M1), the authors establish territory, claim interest or importance by referring to other researchers and by providing citations (Ex 1). They also make generalizations about their topic. ${ }^{2}$

Ex 1

With the wide use of English as a lingua franca in business (Nickerson, 2005, Nickerson, 2013), it has become more important than ever for universities around the world to equip students with the English language skills they need in order to communicate effectively in increasingly globalized economies. (RA-3)

\footnotetext{
${ }^{2}$ All of the examples are selected from the corpus described in "The Corpus" Section. The codes in brackets are the unique identifiers of the texts. For instance, RA-1 stands for Research Article 1 and PhDT- 1 stands for PhD thesis 1 in the corpus.
} 
The second move (M2), "establishing a niche," allows the authors to create a research space for their studies by indicating a gap in previous research(M2S1A), adding to what is known (M2S1B) or by presenting positive justification for their own methodological approach (M2S2) (Ex 2).

Ex 2

My key argument, then, is that, although frequency-based word lists provide a useful long-term goal for learners, they do not provide useful information for a teacher deciding which words to focus on in the classroom. For this, a short list of frequent opaque words (i.e., important words which students are likely to have problems dealing with autonomously) is needed. (RA-15)

After the creation of the research space, in the third move (M3), "presenting the present work, the authors describe how their study will fill this space by presenting their work (Ex 3). They may also present definitional clarifications, their research questions or announce principle outcomes and outline the structure of the paper. However, these steps, except for "announcing the research descriptively" are optional.

Ex 3

In this paper, I produce such a list for undergraduate engineering students and provide details about how the list was developed. (RA-8)

The CARS Model has also been used to ascertain whether PhDT introductions follow the M1-M2-M3 move structure like the RA introductions. Previous studies (e.g., Soler-Monreal et al., in the Spanish context) showed that M2 might be an optional step in PhDTs. As Thompson (30) discusses, although PhDTs share some similarities with RAs is some aspects, apart from the scale of the text, PhDTs are different from RAs in terms of their purpose, readership, the kind of skills and knowledge that their authors are required to display. Thus, the identification of the rhetorical variation across these two genres would assist PhDT authors in the process of writing RA introductions based on their theses.

\section{Methodology}

\section{The Corpus}

The data in this study were two genre-specific corpora: the introduction sections of PhDTs and RAs in Applied Linguistics. The 85663-word PhDT corpus included 25 theses introductions written between the years 2016 and 2020 in $\mathrm{PhD}$ programs in ELT in 5 Turkish universities (table 1). To ensure the validity of the findings, only the theses reporting empirical studies within the field of Applied Linguistics for TESOL were selected. Thus, some of the theses with a different focus such as literature, general education or translation were excluded. The theses were reached through the thesis database of the Higher Education Council. Out of the 11 universities, 5 of them, which contributed regularly over the five years to this database with at least 10 theses were selected. 
Table 1

The Corpus of PhDTs

\begin{tabular}{lllllll}
\hline & AU & ÇOMU & GU & HU & METU & Total \\
\hline $\mathbf{2 0 1 6}$ & 1 & 1 & 1 & 1 & 1 & 5 \\
$\mathbf{2 0 1 7}$ & 1 & 1 & 1 & 1 & 1 & 5 \\
$\mathbf{2 0 1 8}$ & 1 & 1 & 1 & 1 & 1 & 5 \\
$\mathbf{2 0 1 9}$ & 1 & 1 & 1 & 1 & 1 & 5 \\
$\mathbf{2 0 2 0}$ & 1 & 1 & 1 & 1 & 1 & 5 \\
Total & 5 & 5 & 5 & 5 & 5 & 25 \\
\hline
\end{tabular}

Atatürk University (AU)

Çanakkale Onsekiz Mart University (ÇOMU)

Gazi University (GU)

Hacettepe University (HU)

Middle East Technical University (METU)

The 30516-word corpus of the RA introductions was utilized as the reference corpus in this study. It comprised 25 research articles published between the years 2016 and 2020 in SSCI indexed reputable journals in Applied Linguistics (table 2). I selected the journals using two criteria: their ratings among scholars and their impact factors. I asked 15 academics who held a PhD in TESOL to name and rank the 5 most prestigious journals that publish research articles in Applied Linguistics for TESOL. I defined "prestigious journal" as an SSCI journal with a high impact factor in which they would want their research articles to be published in. To assist them in their responses, I provided them with a list of SSCI journals and their impact factors extracted from Scimago journal ranking website (https://www.scimagojr.com). Based on the responses of the informants, I identified five corpus journals: (1) Applied Linguistics, (2) English for Specific Purposes Journal, (3) TESOL Quarterly, (4) System and (5) Journal of English for Academic Purposes, which held the impact factors of (1) 4.28, (2) 2.61, (3) 2.07, (4)1.97 and (5) 1.89 respectively at the time of the study. The corpus texts were selected using both ${ }^{3}$ random and stratified sampling methods to ensure an equal distribution among years, journals and PhD programs. Based on the first names and the affiliations of the authors, it can be commented that RA authors represent a wide range of country origins and first languages in the study and 32\% (N=8) are native speakers of English.

Table 2

The Corpus of RAs

\begin{tabular}{lllllll} 
& AL & ESPJ & System & JEAP & TESOLQ & Total \\
\hline $\mathbf{2 0 1 6}$ & 1 & 1 & 1 & 1 & 1 & 5 \\
$\mathbf{2 0 1 7}$ & 1 & 1 & 1 & 1 & 1 & 5 \\
$\mathbf{2 0 1 8}$ & 1 & 1 & 1 & 1 & 1 & 5 \\
$\mathbf{2 0 1 9}$ & 1 & 1 & 1 & 1 & 1 & 5 \\
$\mathbf{2 0 2 0}$ & 1 & 1 & 1 & 1 & 1 & 5 \\
Total & 5 & 5 & 5 & 5 & 5 & 25 \\
\hline
\end{tabular}

3 I conducted the random selections in this study using the randomizer tool developed by Brezina (2018). 
AL: Applied Linguistics

ESPJ: English for Specific Purposes Journal

JEAP: Journal of English for Academic Purposes

TESOLQ: TESOL Quarterly

\section{Analyses}

In this study I employed both qualitative and quantitative data analyses methods, comprising frequency counts and text analyses of the PhDT and the RA introductions. Before the analyses, the introduction parts of the $\mathrm{PhD}$ theses were compiled and saved electronically. I used Swales' (232) Create a Research Space (CARS) model as the framework for the analysis of the moves and steps in both sub-corpora. In the manual analysis, I followed the ten steps of conducting a corpus-based move analysis suggested by Biber et al. (37, table 3). After the manual analysis I also electronically tagged the corpus using AntMover (laurenceanthony.com), a text structure move analysis software program. The electronic analysis facilitated the extraction of the lexico-grammatical features employed within each move.

Table 3

Steps used to conduct the move analysis (Biber et al. 34)

\begin{tabular}{ll}
\hline Step 1 & Determine rhetorical purposes of the genre. \\
\hline Step 2 & $\begin{array}{l}\text { Determine rhetorical function of each text segment in its local context; } \\
\text { identify the possible move types of the genre. }\end{array}$ \\
\hline Step 3 & $\begin{array}{l}\text { Group functional and/or semantic themes that are either in relative } \\
\text { proximity to reflect the specific steps that can be used to realize a } \\
\text { broader move. }\end{array}$ \\
\hline Step 4 & Conduct pilot-coding to test and fine-tune definitions of move purposes. \\
\hline Step 5 & $\begin{array}{l}\text { Develop coding protocol with clear definitions and examples of move } \\
\text { types and steps. }\end{array}$ \\
\hline Step 6 & $\begin{array}{l}\text { Code full set of texts, with inter-rater reliability check to confirm that } \\
\text { there is clear understanding of move definitions and how moves/steps } \\
\text { are realized in texts. }\end{array}$ \\
\hline Step 7 & $\begin{array}{l}\text { Add any additional steps and/or moves that are revealed in the full } \\
\text { analysis. }\end{array}$ \\
\hline Step 8 & $\begin{array}{l}\text { Revise coding protocol to resolve any discrepancies revealed by the } \\
\text { inter-rater reliability check or by newly "discovered" moves/steps, and } \\
\text { re-code problematic areas. }\end{array}$ \\
\hline Step 9 & $\begin{array}{l}\text { Conduct linguistic analysis of move features and/or other corpus- } \\
\text { facilitated analyses. }\end{array}$ \\
\hline Step 10 & $\begin{array}{l}\text { Describe corpus of texts in terms of typical and alternate move } \\
\text { structures and linguistic characteristics. }\end{array}$ \\
\hline
\end{tabular}


An independent rater, a university lecturer holding a $\mathrm{PhD}$ in Linguistics, and who had a background in discourse analysis coded $20 \%$ of the cases in this study. There was over $80 \%$ agreement between our categorizations. To solve the cases of disagreement, we consulted a third rater, a PhD in ELT who was not familiar with the categories and we reached consensus. Also, I executed an intrareliability test by re-categorizing $20 \%$ of the cases 15 days after my initial categorization. There was more than $95 \%$ agreement between my first and second rounds of coding the corpus.

\section{Findings and Discussion}

The analysis showed that while the CARS Model described the move-step structure of the majority of the RA introductions, it could not fully account for the rhetorical patterns in the PhDT introductions. First, the authors of the PHDT introductions rarely established a niche in the previous research. Instead, they described what motivated them to conduct the study, which was in most cases a problem that they observed in their local teaching/research context. Moreover, they stated the assumptions and scope of their study and made lengthy definitional clarifications which were rarely found in RA introductions. The rest of this section will mainly focus on the variations rather than the similarities across the two sub-corpora as the implications of the study for novice researchers in the following section will be discussed in the framework of the identified variations. The most significant gap across the two corpora seems to be the absence of M2, "establishing a niche" in most PhDT introductions. M2 is an obligatory step in RAs and executed through a rich selection of lexicogrammatical features, which will be presented and exemplified in the following section.

\section{Move Structure of the RA and the PhDT Introductions}

Overall, the Move Analysis revealed that the three moves in the CARS Model, namely, M1, M2 and M3 existed in almost all of the research articles $(\mathrm{N}=24)$ (table 4). However, only less than half of the PhDT introductions $(\mathrm{N}=10)$, contained all three of the moves. The remaining 15 introductions did not contain a M2 (table 5). Although the M1-M2-M3 was the most frequent pattern in the RA introductions, other configurations such as M3-M1-M2 and M1-M3-M2 were also used.

Majority of the RA introductions ( $\mathrm{N}=20)$ in the corpus followed the M1-M2-M3 move structure pattern. As far as the PhDT introductions were concerned, M1M3 pattern was the most commonly preferred combination. In 13 of the introductions, this pattern was employed without any recycling of the moves. In another 3, M1-M3 move structure was recycled (e.g., M1-M3-M1-M3). 
Table 4

Move Patterns and Number of Move Units in the Corpus of the RA Introductions

\begin{tabular}{lll}
\hline RA & Moves & Number of move u \\
\hline RA1 & $1,2,3$ & 3 \\
RA2 & $1,2,3$ & 3 \\
RA3 & $1,2,3,1,3,2$ & 6 \\
RA4 & $1,2,3$ & 3 \\
RA5 & $1,2,3$ & 3 \\
RA6 & $1,2,3$ & 3 \\
RA7 & $1,2,3$ & 3 \\
RA8 & $1,2,3$ & 3 \\
RA9 & $1,3,2,3,2,3$ & 6 \\
RA10 & $1,2,3$ & 3 \\
RA11 & $3,1,2,3$ & 4 \\
RA12 & $1,2,3,1,3,1$ & 6 \\
RA13 & $1,2,1,2,1,2,1,2,1,2$ & 10 \\
RA14 & $1,2,3$ & 3 \\
RA15 & $1,2,3$ & 3 \\
RA16 & 1,3 & 2 \\
RA17 & $1,2,3$ & 3 \\
RA18 & $1,2,3$ & 3 \\
RA19 & $1,2,3$ & 3 \\
RA20 & $1,2,3$ & 3 \\
RA21 & $1,2,3$ & 3 \\
RA22 & $1,2,3$ & 3 \\
RA23 & $1,2,3$ & 3 \\
RA24 & 1,3 & 6 \\
RA25 & $1,2,3$ & 3 \\
& &
\end{tabular}

Table 5

Move Patterns and Number of Move Units in the Corpus of the PhDT Introductions

\begin{tabular}{llc}
\hline Thesis & Moves & Number of move unit \\
\hline PhDT1 & $1,3,1,3$ & 4 \\
PhDT2 & 1,3 & 2 \\
PhDT3 & $3,1,2,3$ & 4 \\
PhDT4 & 1,3 & 2 \\
PhDT5 & 1,3 & 2 \\
PhDT6 & $1,2,3$ & 3 \\
PhDT7 & $1,2,1,3$ & 4 \\
PhDT8 & $1,3,2,3$ & 4 \\
PhDT9 & 1,3 & 2 \\
PhDT10 & $1,2,3,1,3$ & 5 \\
PhDT11 & 1,3 & 2 \\
PhDT12 & 1,3 & 2 \\
PhDT13 & 1,3 & 2 \\
PhDT14 & 1,3 & 2 \\
PhDT15 & 1,3 & 2 \\
PhDT16 & 1,3 & 4 \\
PhDT17 & $1,3,1,3$ &
\end{tabular}




$\begin{array}{lll}\text { PhDT18 } & 1,2,3,1,3,1,3 & 7 \\ \text { PhDT19 } & 1,3,2,1,3 & 5 \\ \text { PhDT20 } & 1,3,1 & 3 \\ \text { PhDT21 } & 1,3 & 2 \\ \text { PhDT22 } & 1,3,1,3,2,3 & 6 \\ \text { PhDT23 } & 1,2,3,1,3 & 5 \\ \text { PhDT24 } & 1,3 & 4 \\ \text { PhDT25 } & 1,3 & 4\end{array}$

\section{Move Structure of the PhDT Introductions}

The Move-Step analysis showed that move structure of the RA introductions was aligned with the CARS Model. However, the Model did not completely account for the PhDT introductions in several aspects. Thus, I adapted the CARS Model to the move structure of PhDT introductions (fig. 2.). The PhDT introductions included two optional steps in Move 1 (establishing a territory): definitional clarifications (M1S2) and description of a local problem (M1S3). More than half $(\mathrm{N}=16)$ of the introductions contained definition of one or more terms in M1. Although most of these introductions contained a separate sub-section with the heading "definition of terms" under Move 3, definition of terms was integrated into Move 1 as well.

Unlike the authors of the RA introductions, the authors of the PhDT introductions tended not to establish a niche or indicate a gap in the previous research. Instead, with increasing specificity, the authors $(\mathrm{N}=23)$ focused on a local problem that motivated them to conduct the study rather than an observed niche in the previous research. (Ex 4 and Ex 5). This might be related to differences in the aim and audience of these two genres. The authors of the PhDTs are not expected to promote their studies in a competitive arena. As Bruce (95) also discusses, another reason might be the authors' reservations in adopting a critical stance towards others' research and making high-level claims about their own research as novice researchers (Ex 6). In fact, in PhDT introductions, "establishing a niche" was likely to take the form of elaborating on a particular research problem, rather than indicating a gap in previous literature.

Ex 4

Nevertheless, in Turkey, Council of Higher Education (CoHE) accepted its implementation in the 2006-2007 academic year... There is a need to make urgent changes within these developments in ELT curriculum that would meet the demands of teachers, students, and the social expectations. (PhDT-2)

Ex 5

Even though many teacher trainers encourage peer-observation, most of the instructors do not like being observed by their colleagues (Balcloğlu, 2010, p.44). So, there is a great need to find out why this form of self-development is not preferred and resented by many instructors and offer some solutions for this. (PhDT-14) 
Ex 6

Previous studies, which found some pros and cons of this current ELT curriculum will construct the frame of evaluation. With the help of previous findings, and the data that will be collected within this study are going to be used in needs analysis. (PhDT-9)

Fig. 2. 2004 Version of the CARS Model (Swales, 2004: 232) Adapted to the PhDT Introductions in this Study

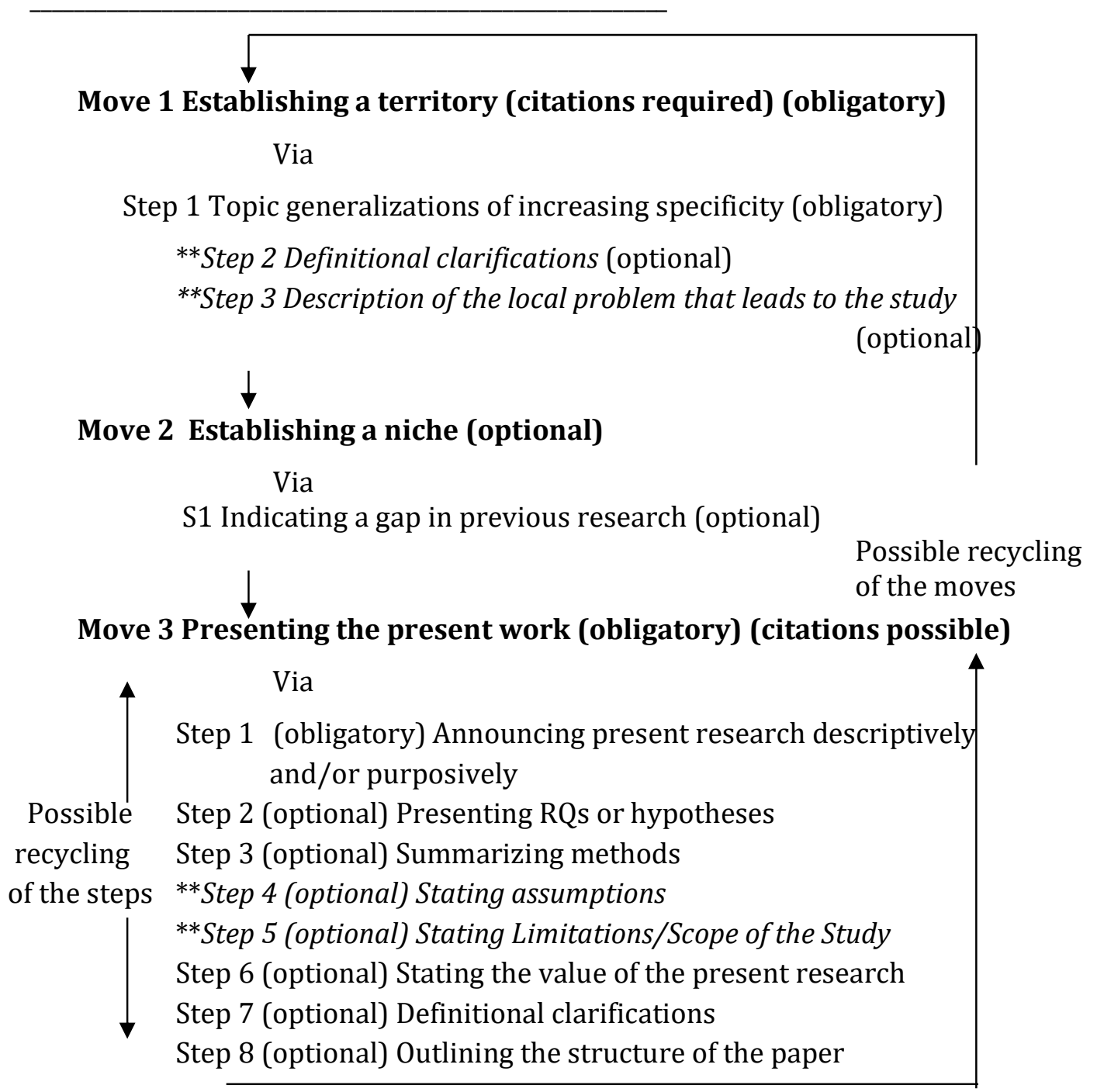

* Steps 2-8 are not only optional but less fixed in their order of occurrence than others.

** The italicized steps are specific to the PhDTs analyzed in this study. They are non-existent in the original CARS Model (Swales 232).

The authors of the PhDT introductions utilized all step options for Move 3, except for Step 5 (announcing principle outcomes). Nevertheless, there were two additional steps, "stating the limitations of the study" (N=18) (Ex 7) and "stating the assumptions" (Ex 8), which were commonly utilized by the authors of the PhDT introductions and which did not exist in the RA introductions. The limitations and the scope of the study were mainly concerned with the research 
design or tools that decreased the generalizability power of the findings. The scope specifically described the aim of the study, while the limitations were related to the research methods, such as the number of subjects. The assumptions such as "the data collection tools are valid and reliable" on the other hand, concerned the authors' proactive clarifications about the aspects of the research that might be prone to criticisms.

\section{Ex 7}

Second, the items on the receptive and productive tests were limited in terms of the number the target collocations to alleviate test fatigue. (PhDT-12)

Ex 8

Therefore, it is assumed that all academics in personal semi-structured interviews, and all students in focus-group interviews answered the questions, willingly, truthfully and in a sincere way. (PhDT-25)

The authors of the RA introductions established the niche in previous research in several different ways. Table 6 lists and exemplifies the linguistic features used in RAs in Move 2 and Table 7 presents the frequency and percentage of these features. As shown in Table 6, in Move 2, the authors used a wide range of lexico-grammatical features including negative and quasi-negative quantifiers (Ex 9), lexical negation using adjectives (Ex 10), verb phrases (Ex 11), verbs (Ex 12) and nouns (Ex 13) as well as questions (Ex 14), structures expressing needs (Ex 15) and contrastive comments (Ex 16).

Table 6

Lexico-Grammatical Features in Ras in Move 2, Establishing a Niche

\begin{tabular}{l|ll} 
& $\begin{array}{l}\text { Linguistic } \\
\text { exponents }\end{array}$ & Example \\
\hline $\begin{array}{l}\text { Negative or quasi- } \\
\text { negative quantifiers }\end{array}$ & $\begin{array}{l}\text { no } 9 \\
\text { less } \\
\text { little } \\
\text { few/very few } \\
\text { only } \\
\text { not much } \\
\text { small number }\end{array}$ & $\begin{array}{l}\text { Less } \text { attention has been paid to the impact of the } \\
\text { discipline on } \text { L2 writing by graduate students }(e . g . \\
\text { Hyland, 2004b). (RA-5) }\end{array}$ \\
$\begin{array}{l}\text { Lexical Negation } \\
\text { Adjectives }\end{array}$ & $\begin{array}{l}\text { unclear } \\
\text { simplistic } \\
\text { understudied } \\
\text { unexplored } \\
\text { rare } \\
\text { problematic } \\
\text { deficit } \\
\text { unsatisfactory } \\
\text { scarce } \\
\text { dubious }\end{array}$ & $\begin{array}{l}\text { Another issue in this SLA tradition is that these } \\
\text { studies generally rely on rather small quantities of } \\
\text { empirical data, often on the basis of a small } \\
\text { number of subjects, which again makes the } \\
\text { generalizability of results dubious. } \text { (RA-25) }\end{array}$ \\
\end{tabular}


Verb phrase

Verb

Noun

\section{Questions}

\section{Expressed need}

not consider not illustrate not represent not been adequately defined hardly received not established not been systematically investigated

Fail

Ignore Overlook neglect

limitation paucity lack confusion
Ex 11

However, the linguistic features and rhetorical purpose of laboratory reports have not been considered in the science education literature, and the present study seeks to fill this gap. (RA-3)

Ex 12

In the LL field, the existing research on learners' ER focuses solely on the strategies tackling negative emotions (NEs) such as anxiety (Bown, 2006; Gkonou, 2018a; Hurd \& Xiao, 2010; Kondo \& YingLing, 2004), neglecting those promoting positive emotions (PEs). (RA-1)

\section{Ex 13}

There is considerable confusion as to whether Translanguaging could be an all-encompassing term for diverse multilingual and multimodal practices, replacing terms such as code-switching, code-mixing, code-meshing, and crossing. (RA-4)

Ex 14

While students' individual differences (e.g., learning objectives, personal needs, education histories, disciplinary practice), as well as their individualized learning trajectories, have gained increasing recognition in recent ESP studies of instruction-based genre learning, the question arises as to whether students learning together in a genre-focused ESP class have any characteristics in common that may also influence the genre learning process and may need consideration in ESP genre-focused pedagogy. (RA24)

\section{Ex 15}

Sensitivity to micro, meso, and macro levels necessitates a deconstruction of what "English" means to stakeholders and entails a reflexive dialogue about deeply held beliefs of English, language and communication in local contexts (Pennycook, 2010, Sifakis, 2017). (RA-6) 
Contrastive Comment

Table 7

Frequency and Percentage of Lexico-Grammatical Features in Move 2 in RAs

\begin{tabular}{l|lll}
$\begin{array}{l}\text { Lexico- } \\
\text { Grammatical } \\
\text { features }\end{array}$ & Frequency & $\%$ & $\begin{array}{l}\text { Normalized } \\
\text { Frequency } \\
\text { (Per 1000 words) }\end{array}$ \\
\hline $\begin{array}{l}\text { Negative or quasi- } \\
\text { negative }\end{array}$ & 7 & 17 & 5.2 \\
$\begin{array}{l}\text { quantifiers } \\
\text { Lexical negation }\end{array}$ & 25 & & \\
$\begin{array}{l}\text { Questions } \\
\begin{array}{l}\text { Expressed need } \\
\text { Contrastive }\end{array}\end{array}$ & 2 & 60.9 & 18.6 \\
comment & 5 & 4.8 & 1.4 \\
& & 4.8 & 3.7 \\
\end{tabular}

\section{Conclusion and Implications}

This study was a contrastive analysis of the genre-specific features of the PhDT and the RA in Applied Linguistics for TESOL. The findings of this study might have important implications for novice writers who would like to publish their studies in academic journals and more specifically, who would like to transform their PhDTs into RAs. In this respect, the findings might be utilized in the supervision of graduate students of Applied Linguistics to help them more effectively respond to the expectations of their discourse community. Such guidance would assist them in their academic socialization process of learning how to write in the way deemed appropriate by the expert discourse communities in their fields.

One important finding revealed by the rhetorical move structure analysis was that unlike the RA authors, the PhDT authors tended not to criticize previous studies or indicate the gap in previous knowledge, which is an essential move in highlighting the significance of the study. In this respect, novice writers might need explicit guidance in creating Move 2, establishing a niche, in the CARS Model. To this end, they might benefit from the rhetorical strategies identified in this study (e.g., table 6) and the strategies in similar studies in social sciences and humanities (e.g., see Lu et al. 70 for phrase frames and Afros and Schryer 59 for metadiscourse strategies) in writing their RA introductions.

A second aspect that deserves attention by the novice writers would be adjusting the contents and organization of their introductions according to the expert level and expectations of the RA editors and readership. Thus, avoiding 
the steps of lengthy definitional clarifications and proactive assumptions about their research design would help them establish a more confident voice in reporting their studies to an expert audience.

From a pedagogical perspective, three main directions might be followed to raise the graduate students' awareness of the rhetorical features of RA introductions. The first is adopting an apprenticeship approach (Pecorari 26) in thesis supervision, which is in fact the co-authoring of a research article by the post-graduate student and the supervisor of the thesis. The second approach entails more explicit integration of genre-based academic writing support into the curriculum and the thesis writing supervision of the students (Swales, 1987; Li 175; Peacock 493; Farley 5). For instance, Swales and Feak (187) provide a number of awareness raising tasks geared towards the effective implementation of the CARS Model by graduate students. The last direction is concerned with the shift of PhD programs' expectations as regards the format and discourse organization of the $\mathrm{PhD}$ thesis. Instead of the traditional thesis with the classic IMRAD pattern, the students might be required to write a thesis in the form of a compilation of research articles (Paltridge 137).

This study specifically focused on the genre-specific features of introductions in a corpus of PhDTs in Applied Linguistics for TESOL written in PhD programs offered by Turkish universities and in a corpus of research articles published by expert authors in five mainstream international academic journals in the same field. The findings and implications might be more generalizable with future research focusing on contrastive genre-specific discourse analysis of different sections of PhDTs and RAs written by authors in other international publication and research settings.

\section{Works Cited}

Afros, Elena and Catherine, F. Schryer. "Promotional (Meta)Discourse in Research Articles in Language and Literary Studies." English for Specific Purposes, vol. 28, no. 1, 2009, pp. 58-68.

Anthony, Laurence. AntMover (Version 1.1.0) [Computer Software]. Waseda University, 2003. Available from https://www.laurenceanthony.net/software.

Bakhtin, Mikhail Mikhaillovitch. Speech Genres and Other Late Essays. University of Texas Press, 1994.

Bhatia, Vijay, K. "Genre-Mixing in Academic Introductions." English for Specific Purposes, Vol. 16, no. 3, 1997, 181-195.

---. Worlds of Written Discourse. Continuum, 2004.

Berkenkotter, Carol and Thomas Huckin, N. Genre Knowledge in Disciplinary Communication: Cognition/Culture/Power. Lawrence Erlbaum Associates, Inc, 1995.

Biber, Douglas et al., Discourse on the Move. John Benjamins Publishing Company, 2007.

Brezina, Vaclav. Statistics in Corpus Linguistics. Cambridge University Press, 2018. http://corpora.lancs.ac.uk/stats. 
Bruce, Ian. "Expressing Criticality in the Literature Review in Research Article Introductions in Applied Linguistics and Psychology." English for Specific Purposes, no. 36, 2014, 85-96.

Farley, C. Peter. "Using Role-Play to Teach Novice Writers the Expectations of Journal Editors and Reviewers." English for Specific Purposes, vol. 55, 2019, 1-11.

Harwood, Nigel. "Nowhere Has anyone Attempted...In this article I aim to do just that" A Corpus Based study of Self-Promotional $I$ and We in Academic Writing across Four Disciplines." Journal of Pragmatics, vol. 37, 2005, 1207-1231.

Hirano, Eliano. "Research Article Introductions in English for Specific Purposes: A Comparison between Brazilian Portuguese and English". English for Specific Purposes, Vol. 28, no: 4, 2009, 240-250.

Hyland, Ken and Feng (Kevin) Jiang. English for Specific Purposes, vol. 51, 2013, 18-30.

Kamler, Barbara and Pat Thomson. Helping Doctoral Students write: Pedagogies for Supervison. Routledge, 2014.

Kanoksilapatham, Budsaba. "Distinguishing Textual Features Characterizing Structural Variation in Research Articles across three Engineering Sub-Discipline Corpora." English for Specific Purposes, vol. 37, 2015, 74-86.

Li, Yongyan. "Negotiating Knowledge Contribution to Multiple Discourse Communities: A Doctoral Student of Computer Science Writing for Publication." Journal of Second Language Writing, no. 15, 2006, 159-178.

Linell, Per. Approaching Dialogue: Talk, Interaction and Contexts in Dialogical Perspectives, John Benjamins Publishing Company, 2001.

$\mathrm{Lu}$, Xiaofei et al. "Matching Phrase-Frames to Rhetorical Moves in Social Science Research Article Introductions." English for Specific Purposes, no. 61, 2021, 63-83.

Mogaddasi, Shain and Heather A. B., Graves. "Since Hadwiger's Conjection ... is Still Open": Establishing a Niche for Research in Discrete Mathematics Research Article Introductions." English for Specific Purposes, no. 45, 2017, 69-85.

Öztürk, İsmet. The Textual Organisation of Research Article Introductions in Applied Linguistics: Variability within a Single Discipline. English for Specific Purposes, Vol. 26, no. 1, 2007, 25-38.

Paltridge, Brian. "Thesis and Dissertation Writing: An Examination of Published Advice and Actual Practice." English for Specific Purposes, no. 21, 2002, 125-143.

Peacock, Matthew. "Communicative Moves in the Discussion Section of Research Articles." System, no. 30, 2002, 479-497.

Pecorari, Diane. "Visible and Occluded Citation Features in Postgraduate SecondLanguage Writing”. English for Specific Purposes, no. 25, 2006, 4-29.

Samraj, Betty. "Introductions in Research Articles: Variations across Disciplines." English for Specific Purposes, Vol. 21, 2002, 11-17.

Soler-Monreal, Carmen et al. "A Contrastive Study of the Rhetorical Organisation of English and Spanish PhD Thesis Introductions." English for Specific Purposes, Vol. 30, no. 1, 2017, 4-17.

Swales, John M. Research Genres: Exploration and Applications. Cambridge University Press, 2004.

Swales, John. M. and Christine, B. Feak. English in Today's Research World: A Writing Guide. University of Michigan Press, 2000. 
Tessuto, Girolamo. "Generic Structure and Rhetorical Moves in English-Language Empirical Law Research Articles: Sites of Interdisciplinary and Interdiscursive Cross-Over." English for Specific Purposes, vol. 37, 2015, 13-26.

Thompson, Paul. (Ed). Issues in EAP Writing Research and Instruction. CALS, 1999.

Wang, Weihong and Chengsong Jang. "Claiming Centrality as Promotion in Applied Linguistics Research Article Introductions." Journal of English for Academic Purposes, Vol. 20, 2015, 162-175. 